ISSN 1981-416X

Licenciado sob uma Licença Creative Commons

\title{
Antecipação e formação: o pensamento utópico e o paradoxo da formação humana
}

\author{
Anticipación y formación: el pensamiento utópico \\ y la paradoja de la formación humana
}

\begin{abstract}
Anticipation and development: the utopian thought and the paradox of human development
\end{abstract}

\section{Juliano Peroza*}

\section{Resumo}

Este artigo objetiva apresentar as tensões paradoxais entre o pensamento utópico e a formação humana. Os pressupostos teórico-metodológicos da investigação são a hermenêutica e a pesquisa bibliográfica, com a finalidade de compreender e interpretar esta interrelação entre utopia e formação. Na primeira parte, será apresentada uma discussão histórica e filosófica sobre a utopia e a educação, de modo a demonstrar, desde a antiguidade até a modernidade, algumas concepções de formação intuídas a partir de referenciais do pensamento utópico e que estão nas matrizes do pensamento ocidental, com base nas referências de Platão (2006), Cambi (1999), Jaeger (2010) e More (1997). Na segunda parte se discute sobre os pressupostos epistemológicos do pensamento utópico, compreendido como a visão do "ainda-não-consciente" que dialetiza na história a busca do "já-ainda-não", com base nas obras de Bloch (2005, 2006). E, por fim, refletiremos

*JP: Doutor em Educação, e-mail: juliano.peroza@ifpr.edu.br 
sobre o paradoxo da formação humana em diálogo com os referenciais do pensamento utópico Furter (1968; 1977/78). Conclui-se que a formação humana na perspectiva do pensamento utópico revela um paradoxo: a problematização do devir humano no horizonte de uma conclusão-inconclusa.

Palavras-chave: Utopia. Paradoxo. Formação Humana.

\section{Resumen}

Este artículo tiene como objetivo presentar las tensiones paradojales entre el pensamiento utópico y la formación humana. Los presupuestos teórico-metodológicos de la investigación son la hermenéutica y la investigación bibliográfica, que utilizamos con la finalidad de comprender e interpretar esta interrelación entre utopía y formación. En la primera parte, se presentará una discusión histórica y filosófica sobre la utopía y la educación, para demostrar, desde la antigüedad hasta la modernidad, algunas concepciones de formación intuidas a partir de referencias del pensamiento utópico y que están en las matrices del pensamiento occidental, sobre la base de las referencias de Platão (2006), Cambi (1999), Jaeger (2010), More (1997). En la segunda parte, se discute sobre los presupuestos epistemológicos del pensamiento utópico, comprendido como la visión del "todavía-no-consciente" que dialectiza en la historia la búsqueda del "ya-todavía-no", con base en las obras de Bloch $(2005,2006)$. Al finalizar, reflexionamos sobre la paradoja de la formación humana en diálogo con los referentes del pensamiento utópico Furter (1968, 1977/78). Se concluye que la formación humana en la perspectiva del pensamiento utópico revela una paradoja: la problematización del devenir humano en el horizonte de una conclusión-inconclusa.

Palabras clave: Utopia. Paradoja. Formación humana. 


\section{Abstract}

This article aims to present the paradoxical tensions between the utopian thought and human development. The theoretical and methodological premises of the investigation are hermeneutics and bibliographical research, with the purpose of understanding and interpreting the link between utopia and development. Firstly, there will be a historical and philosophical discussion on utopia and education, in order to demonstrate, from ancient times up till now, some concepts of development perceived through reference of the utopian thought, which are in the foundations of Western thought, based on the references of Platão (2006), Cambi (1999), Jaeger (2010), More (1997). Secondly, a discussion is made on the epistemological premises of the utopian thought, understood as the view of the "still-not-aware", which dialectises into history the search for the "already-still-not", based on the works of Bloch (2005. 2006). And, lastly, there shall be a reflection on the paradox of human formation in dialog with the reference for utopian thought Furter (1968; 1977/78). It may be concluded that human development, in the perspective of utopian thought, reveals a paradox: the problematization of what's to come for the human species, with an inconclusive-conclusion in the horizon.

Keywords: Utopia. Paradox. Human Development.

\section{Introdução}

O pensamento utópico, seja qual for a expressão de sua manifestação - religiosa, política, social, econômica, literária, educacional, etc, - sempre esteve presente na trajetória da cultura ocidental. Em geral, seus representantes demonstraram estar profundamente comprometidos com a realidade de seu tempo, o que demonstra que a maioria das utopias provoca uma reflexão crítica de uma época circunstanciada, do mesmo modo que o imaginário que elas propõem, seu ideal, é sempre concebido em função dos valores reinantes na sociedade real (AINSA, 1991, p. 13).

Para a reflexão filosófica e pedagógica, o pensamento utópico se apresenta como um referencial fecundo de problematização sobre 
os fundamentos da educação e da ação educativa. Ele nos provoca a circunstanciar, em cada época, os pressupostos teleológicos que se constituem como horizontes da formação humana e, obviamente, demarcam os critérios de insubordinação a toda e qualquer forma de obstrução, seja ela política ou ideológica, da efetivação deste "devir humano" em consonância com estes pressupostos. Dito em outras palavras, a utopia confere sentido à liberdade humana para que o homem assuma a tarefa de configurar seu ser em referência às possibilidades históricas de sua própria plenificação existencial numa determinada época.

A partir deste panorama, somos provocados a refletir sobre as dimensões do estatuto epistemológico da utopia enquanto imaginário construtor de outra realidade possível e a educação enquanto formação, que representaria a configuração da existência humana em-e-para-além da sua época e do seu lugar. Isso implica em reconhecer um modelo de homem a ser escolhido (uma possibilidade) para ser cultivado, aperfeiçoado ou aprimorado, a fim de que realize o potencial que lhe é inerente sem perder de vista as dimensões culturais e históricas do seu tempo. Mas, qual seria o critério de validade para assumir um modelo de ser humano em detrimento de outro em relação às inúmeras latências antropológicas contidas na realidade existente?

Para responder a esta pergunta, postulamos a necessidade de uma criteriosa reflexão sobre os elementos centrais que constituem as bases do pensamento utópico, que explicitam seus fundamentos e suas características, bem como demonstram suas implicações paradoxais para a formação humana.

Entende-se, aqui, paradoxo não na perspectiva de um dilema, ou um impasse lógico, mas em seu sentido literal (П $\alpha \rho \alpha ́ \delta o \xi \alpha)$, que significa ser "contrário à opinião", ou "contrário à opinião recebida e comum". A noção de paradoxo porta em si a problematização da novidade, de argumentos que fundamentam um contrassenso que "maravilha por que propõe algo que parece assombroso, que possa ser tal como se diz como é" (MORA, 2004, p. 2203). 
Na medida em que o pensamento utópico desperta nos indivíduos a rejeição ao status quo e os engaja em ações afirmativas inéditas, pode-se dizer que exerce uma ação formativa e formadora de uma consciência autônoma. Esta não se restringe a uma adaptação conveniente à realidade e, nem se deixa acomodar à naturalização dos acontecimentos e ao determinismo dos fatos. Daí que a utopia seja um despertar para formas inéditas do "vir-a-ser" e, ao mesmo tempo, uma recusa à cristalização de formas definitivas e acabadas no que se refere às concepções deterministas e imutáveis do ser humano, como se houvesse uma "essência" que servisse de referencial para, simplesmente, ser atualizada.

Eis que emerge, portanto, uma questão paradoxal na relação entre o pensamento utópico e a formação humana: estabelecer e, ao mesmo tempo, demolir fronteiras. No mesmo instante em que se estabelecem as fronteiras dos referenciais para a formação humana (sua conclusão), deve se considerar sua efemeridade, condição para sua própria desconstrução (inconclusão). A cada geração se impõe a tarefa de elaborar a crítica do que nega a sua humanização, bem como de arquitetar os horizontes de sua própria afirmação. Um paradoxo que revela o núcleo do pensamento dialético, no qual a superação que emerge da contradição também se torna uma nova tese a ser superada.

Sonhar não é privilégio de indivíduos situados num determinado tempo ou determinada cultura. A capacidade (e a liberdade para) de sonhar é uma condição antropológica, ou seja, é inerente à condição humana que busca continuamente, de acordo as devidas circunstâncias, projetar-se para além de todos os condicionantes de sua temporalidade. Compreender as relações paradoxais entre as dimensões do sonho e suas exigências para a formação humana será o núcleo desta reflexão. 


\section{Utopia e educação: considerações históricas e filosóficas a partir das concepções de formação que fundaram as matrizes do pensamento utópico ocidental}

O problema da relação entre utopia, educação e a formação humana remonta às origens do pensamento grego. Platão, ao descrever sua Calípolis (cidade bela, porquê justa), com seus argumentos a respeito do modelo ideal de formação humana (Paideia) numa cidade perfeita, teria estabelecido um marco na história da educação e da utopia, com sua obra A República (2006). O caráter idealista desta obra reflete os pressupostos básicos da filosofia platônica, a qual é entendida como ciência dos princípios do conhecimento que está no "mundo inteligível", no qual se encontram as ideias correspondentes às formas da realidade em si.

A educação, de acordo com Jaeger (2010, p. 830), assumiria um valor fundamental na República, pois seria por meio desta que se aprimorariam os indivíduos para que cumprissem, devotamente, as funções correspondentes à sua condição na classe em que se encontram para dar, consequentemente, uma possível estabilidade ao todo social. Somente pela educação seria possível cultivar o melhor de cada indivíduo de acordo com a sua própria natureza. Esse projeto educativo-utópico-idealista implica que se reconheça a necessidade de uma constante vigilância disciplinar para que cada indivíduo cultive a virtude que corresponde à qualidade de sua alma. A finalidade disso seria o processo de aperfeiçoamento das novas gerações de homens, de acordo com as virtudes que correspondessem às características de sua alma/classe, como se fosse possível "ascender" de nível, enquanto humanidade. Esta, contudo, aprimoraria moralmente sua conduta, segundo as diretrizes orquestradas por uma determinada classe dirigente (os reis filósofos, ou filósofos reis), os únicos que teriam a capacidade de intuir as características do Bem Supremo e traduzi-las em forma de justiça na sociedade.

Por conseguinte, para se refletir sobre utopia e educação nas origens do Ocidente, é imprescindível também que seja dada uma especial atenção à contribuição do cristianismo primitivo, em sua originalidade 
efervescente, como promotor de um novo ethos sociopolítico orientado por uma nova noção de reinado, o Reino de Deus. A noção deste reinado, promulgado e vivido por Jesus e seus seguidores, na região da Palestina, será o pano de fundo no qual se depositarão os conteúdos da utopia cristã, e do potencial ecumênico (no sentido das palavras gregas oikos/ menein - administração da casa, ou oikoumenikos: toda a casa habitada. Por extensão, toda a terra habitada) do cristianismo, também herdeiro da vertente profética judaica.

Neste sentido, um fato decisivo para a consolidação da teologia cristã em relação aos pressupostos da filosofia grega como uma "fusão conceitual" consistente, para as bases de um novo projeto utópicoeducativo religioso, foi o surgimento da "patrística". Ou seja, a tradição apostólica continuada por intelectuais "consagrados”, que passaram a ser denominados de Padres da Igreja. Foram eles os primeiros defensores ou apologetas do cristianismo, que exercitaram uma aproximação entre os pressupostos da fé cristã e os fundamentos da filosofia grega, a fim de legitimar o cristianismo, na medida em que este fosse interpretado em conformidade com o horizonte das categorias do pensamento helênico, para superá-las, num exaustivo confronto interpretativo:

Clemente, com seu Paedagogus, coloca como modelo a Paideia helênica, mas também afirma que esta só se realiza plenamente no cristianismo. O cristianismo é portador de uma nova Paideia, embora devedora da antiga. Segundo Orígenes, "Cristo era o grande Mestre" que indicava uma "Paideia do gênero humano", mas isto implicava uma estreita colaboração entre cultura grega e cristianismo: de modo que o cristianismo se nutrisse daquela cultura e a superasse. Com Clemente e Orígenes muda também o papel do educador: este se torna guia espiritual e cultural e oferece os instrumentos para chegar à "sapiência" e a um crescimento espiritual interior (CAMBI, 1999, p. 128).

A Paideia, termo que designa o ideal de formação clássica do homem grego (JAEGER, 2010), passa a estimular os padres apostólicos a empenharem seus esforços para argumentar e defender a supremacia 
da mensagem do Cristo (Alfa e Ômega) como centralidade e universalidade no que se refere ao modelo perfectível de ser humano a ser formado. Deste modo, Jesus seria o novo critério, ao qual toda e qualquer afirmação filosófica deveria estar sujeita. Como imagem humana do que representa a própria efetivação histórica do absoluto, Jesus passa a ser o logos encarnado (Jo 1, 1), única base sobre a qual deveriam ser depositados os esforços intelectuais para assegurar a solidez de uma reflexão genuína, a fim de que a razão fosse precedida, plenificada e iluminada pela fé. Ao se apropriar dos elementos culturais do pensamento grego para superá-los, o período da patrística consolida os princípios de universalização do cristianismo para a cultura ocidental. Assume também a identificação da pessoa de Jesus como o modelo perfectível de humanidade a ser imitado — Imitatio Christi (KEMPIS, 1987).

Assim, Agostinho de Hipona, ao buscar as bases de seu pensamento no idealismo platônico, elabora uma espécie de síntese teológico-filosófica que influenciará os rumos da Igreja e da história do Ocidente por séculos. Sua análise da "história da salvação rumo ao reino" (BLOCH, 2006, p. 59) compreende a historicidade como limite de um processo que se interrompe no aqui e agora - hic et nunc - , mas tem seu alvo final no além tempo/espaço, na Civitas Dei - Cidade de Deus aquela que comportaria o caráter atemporal da plenitude e da eternidade bem aventurada de todos em Deus: "Deus estabeleceu uma divisão entre a Cidade de Deus, que não peregrina nesta mortalidade, mas é eternamente imortal [...]" (AGOSTINHO, 2012, parte II, p. 65). Por isso, a Igreja prefiguraria na terra a imagem parcial desta "cidade suprema", possuindo a autoridade "pedagógica" de conduzir a todos os que se reunissem sob seu escopo, sejam pecadores (que por graça receberiam a misericórdia divina), sejam os eleitos, para o "lugar celestial".

Posteriormente, a emergência do contexto renascentista foi o fato histórico marcante que simbolizou o despertar efervescente da imaginação e da criatividade de intelectuais e artistas em vistas da construção de uma realidade totalmente nova, que já estaria emergindo a partir da antiga. No âmbito da sociedade surgiram projetos inéditos que 
revelaram o potencial criador da inteligência humana, de modo que os "esboços de um mundo melhor" abarcaram, desde a medicina aos sistemas sociais; das tecnologias à arquitetura, da geografia à arte" (BLOCH, 2006, p. 9). O mundo passou a ser visto como uma vasta gama de possibilidades, passível de intervenção e investigação racional, pois o desenvolvimento e aprimoramento das condições técnicas objetivaram inúmeras conquistas que até então jamais haviam sido sequer cogitadas.

Expressão singular desta época no que se refere à leitura crítica, original e criativa, enquanto proposta de superação das mazelas sociais da sua realidade, bem como de problematização sobre as contradições das instituições de seu tempo, foi o filósofo humanista, autor da obra Utopia, Thomas More (1478-1535). A sociedade, para More, torna-se a grande comunidade em que se promoveriam e imprimiriam as características morais nos indivíduos. Assim, esta deveria se organizar de forma preventiva, a fim de propiciar o "florescimento da virtude" em meio à juventude, e não sua degeneração massiva, a promoção da corrupção, de modo que em sua maturidade não lhes restassem outra opção a não ser a condenação e a repressão física. Por isso, na ilha de Utopia, More descreve o cuidado prioritário que é dedicado às crianças, portadoras de "almas tenras e impressionáveis" que devem ser formadas para, no futuro, assegurar a salvaguarda do Estado (MORE, 1997, p. 125), condição que se assemelha à d'A República, de Platão, elemento indispensável para a vigência da incorruptibilidade dos costumes entre os cidadãos.

No entanto, para além do idealismo platônico, Thomas More, com sua Ilha Utopia, inaugura uma nova modalidade epistêmica na história do pensamento utópico que explica sua originalidade em dois sentidos: primeiro, pelo fato de ter cunhado o termo "utopia" até então inexistente. Segundo, ao mesmo tempo em que denunciava as contradições vigentes na realidade de sua época, anunciava a possibilidade de sua superação a partir de um contraponto imaginado - não meramente "ideal" - em seus pormenores, com a erradicação da propriedade privada e o equilíbrio entre dois princípios válidos para a coletividade: o lazer e o trabalho. No 
que se refere ao termo Utopia, e a intencionalidade real de superar o idealismo platônico, Cosimo Quarta (2006) explica:

O passo adiante que Morus julga ter cumprido em relação a Platão, é o de apresentar o "estado ótimo" como já realizado e operante[...]. Morus nos diz que a ou-topia, o pensamento crítico, o negativo, não tem fim em si mesmo, mas deve, necessariamente, se não quiser ser estéril, reconciliar-se com o "positivo" e desembocar em um projeto de "sociedade boa". Em suma, se o ponto de partida é a "ou-topia", o ponto de chagada deve ser a "eu-topia" (QUARTA, 2006, p. 48).

A categoria ou-topos - lugar que não existe - prevaleceu sobre sua variante eu-topos - lugar do bem — de modo que esta obra de More ficou reconhecida, historicamente, como mais um gênero literáriofilosófico abstrato, sem pretensões políticas e sociais. No entanto, o postulado de um "não-lugar" enquanto negação das negatividades reais de um determinado "lugar" contextualizado - diga-se a Inglaterra, Europa, etc. - sugere uma tensão entre o ainda-não do agora e o inédito. As negatividades do lugar existente, que também são sinônimos daquilo que não está bom no lugar que existe, implicam, necessariamente, a afirmação da positividade, de um lugar do bem, superação de sua contradição.

A riqueza semântica da palavra utopia em More é portadora de uma sutil ambiguidade, quase de uma paradoxidade — de uma tensão originária que busca equilibrar o realismo da crítica denunciante e, ao mesmo tempo, a lucidez do otimismo que anuncia uma realidade diferente. Neste sentido, sua Ilha se torna sinônimo das possibilidades humanas numa sociedade realmente emancipada. Seu apurado senso conjuntural de realidade atinge em cheio o contexto de perversão político-econômica do capitalismo nascente que coabitava com o alvorecer surpreendente das descobertas técnico-científicas.

A Ilha d'A Utopia, de More, se constituiu, simbolicamente, como a possibilidade de uma nova ordem social que eclodiria em seguida, na modernidade. Assim, aos poucos, foram surgindo outras formas imaginárias de conceber a vida social regidas pelo melhor ordenamento 
possível: a Nova Atlântida, de Francis Bacon; a Cidade do Sol, de Campanella, com sua utopia da ordem social; a formulação da noção de Direito Natural, a fim de salvaguardar a liberdade e a dignidade humanas, prerrogativas das utopias sociais; até chegar às utopias federativas no século XIX, com Owen e Fourier; as utopias centralistas, com Cabet e Saint-Simon; os utopistas individuais e os anarquistas, com Stirner, Proudhon e Bakunin (BLOCH, 2006, p. 77-123).

Com esta apresentação pretendemos demonstrar a relevância histórica e a centralidade epistêmica que os temas da utopia e da educação, na perspectiva da formação humana, tiveram ao longo da tradição filosófica Ocidental, principalmente para a Filosofia da Educação. Sobre isso afirma o educador suíço Pierre Furter:

É por isso que de Thomas More à Babeuf, de Henri de Saint-Simon à Proudhon, de Jean-Jaques Rousseau à Pestalozzi, da Educação Nova à conscientização de Paulo Freire, há uma história paralela de reformas sociais e educativas que, através dos séculos, demonstram que o pensamento utópico quer de toda maneira aprimorar as sociedades e formar os homens para lhes tornar capazes de construir uma sociedade igual, justa e fraterna (FURTER, 1977/1978, p. 4, Tradução nossa).

A tematização sobre a utopia e os fundamentos da educação enquanto formação humana sempre estiveram presentes na tradição filosófica ocidental. A própria noção de formação humana pressupõe a ideia de humanização como possibilidade de galgar um nível superior de humanidade, uma condição de aperfeiçoamento. Em suma, trata-se de compreender a formação como processo do devir humano, mediante o qual o indivíduo, enquanto ser natural, devém um ser cultural, pessoa (SEVERINO, 2006). O pensamento utópico, de modo geral, visa a problematização destas possibilidades, bem como a reflexão crítica sobre aquilo que nega a viabilização deste "ser-mais". 


\section{O pensamento utópico: Ernst Bloch e o ainda-não-consciente}

A delimitação epistemológica em torno da temática da utopia tem o propósito de compreender a origem, os fundamentos, as características, as variáveis e os limites deste conceito numa perspectiva rigorosa, objetiva e abrangente. Neste sentido, o filósofo alemão Ernst Bloch (1885-1977) preenche todos estes quesitos, pois quase a totalidade de sua vasta produção intelectual acadêmica esteve voltada para a problemática do pensamento utópico e da esperança de um modo exaustivo e minucioso. O recurso a um de seus intérpretes, o educador suíço Pierre Furter (1968; 1977/78), servirá de base para prospectarmos os traços centrais de nossa reflexão sobre o pensamento utópico e a formação humana.

As considerações filosóficas de Ernst Bloch sobre $O$ princípio esperança (2005; 2006), partem de uma análise radical sobre aquilo que seria o início, o ponto de partida concreto, de onde se originam as expectativas, os desejos, os anseios humanos que se arvoram, esperançosamente, em sonhos de um futuro melhor. Lugares esses que simbolizam a negação completa do sofrimento presente e a plenificação daquilo que é bom, e que, por conseguinte, deve ser preservado e cultivado. Na visão de Bloch, todo o anseio humano tem uma direção, busca algo, tem um alvo. Diferentemente dos animais, que são movidos meramente pela satisfação dos apetites imediatos, os seres humanos têm uma dimensão mais ampla e complexa desta pulsão que se denomina desejo, situação em que aquele que é despertado pelo apetite, imagina a forma do objeto que traria a satisfação.

Bloch concluirá a exigência deste denominador fundante da esperança ao tecer uma contundente crítica à interpretação Freudiana e, mesmo, aos representantes dissonantes da corrente psicanalítica (Adler e Jung), por terem unilateralmente reduzido à sexualidade as origens das pulsões humanas e terem desconsiderado a importância da "fome" como pulsão fundamental de autopreservação, condição para o movimento de todas as outras pulsões (BLOCH, 2005, p. 67).

Deste modo, toda e qualquer forma de desejo libidinoso é secundária ao moribundo que está faminto, de maneira que sua atenção 
é coordenada, em primeiro lugar, em vista do senso de autopreservar sua existência por mais um instante. Somente depois é que as outras pulsões são possíveis; mas a fome precisa ser saciada imediatamente: "o estômago é a primeira lâmpada na qual deve ser derramado o óleo. Seu anseio é preciso, sua pulsão tão inevitável que nem mesmo pode ser recalcada por muito tempo" (Ibidem, p. 68).

Assim, o princípio esperança tem seu marco inicial na fome, que após ter sido controlada, manifesta-se na totalidade do corpo humano que quer se expandir e satisfazer-se na busca de outros alvos. Obviamente, neste momento, o desejo humano já pode vislumbrar o "além-refeição". Sem as ameaças de privação alimentar, pode mapear o universo das múltiplas carências secundárias e fazer disso o laboratório da imaginação. Essa imaginação, que agora passa a ser capaz de criar, arquitetar sonhos, e mais do que isso, abrir os caminhos que conduzam ao seu alcance.

Nestes termos, é possível identificar o ponto crucial no qual Bloch pressupõe estar a gênese constituinte daquilo que se pode denominar de "imaginação utópica": o caráter desejante que impulsiona o ser humano na construção dos sonhos diurnos:

O que é intuído pelo impulso de auto expansão para a frente é, antes, como será demonstrado, um ainda-não-consciente, algo que no passado nunca esteve consciente nem tinha existência, ou seja, ele próprio uma meia-luz para frente, rumo ao novo. Trata-se da meialuz que pode envolver os sonhos diurnos mais simples: a partir dali ela alcança as áreas mais extensas da privação negada, ou seja, da esperança (BLOCH, 2005, p. 79).

Os "sonhos diurnos" são o primeiro esboço da imaginação utópica e articulam, por meio da intuição, as possibilidades de realização dos anseios. Eles brotam daquilo que é mais elementar na existência humana, o aspecto desejante, e evidenciam de forma intuitiva as possibilidades de realização plenificante do desejo. Contudo, convém que se estabeleça uma relação de complementariedade entre o alvo esperançosamente mirado e a pulsão desejante: sem os desejos, a esperança seria vazia, desprovida 
de um conteúdo movente; já os desejos, sem a esperança como guia e referência, seriam cambiantes, sem rumo e perspectiva de direção, e visariam somente a consumação das necessidades de forma puramente imediata e irracional (FURTER, 1968, p. 86).

É evidente que Bloch também procura correlacionar umbilicalmente o pensamento utópico e a tomada de consciência. O "ainda-não-consciente" precisa se tornar consciente, pois o futuro autêntico precisa ser atualizado por meio da consciência atuante na história, que se apropriou das tendências do seu contexto e soube captar a substancialidade da novidade possível de ser experimentada, mas, que até então não havia sido percebida. O "olhar para frente" se amplia no horizonte, a imagem distante ganha nitidez e faz avançar sem receio. A esse respeito, Bloch afirma:

O olhar para frente se torna tanto mais aguçado quanto mais claramente se torna consciente. Nesse olhar, o sonho quer ser plenamente claro; a intuição, correta, evidente. Só quando a razão toma a palavra, a esperança, na qual não há falsidade, recomeça a florescer. O próprio ainda-não-consciente deve se tornar consciente quanto ao seu ato, consciente de que é uma emergência [...] a esperança não surge mais como uma emoção autônoma, mas de modo consciente-ciente como função utópica (BLOCH, 2005, p. 143-144).

A imaginação utópica tem a função de despertar a consciência do indivíduo para a avaliação das condições de possibilidade de intervir com precisão na realidade, para que o "vir-a-ser" pretendido se manifeste concretamente e promulgue as bases de uma nova ordem, para, dessa forma, romper com o invólucro determinista da antiga ordem. Isto implica em que seja superada uma determinada condição de alienação, uma tomada de distância diante de uma dada situação, para que melhor se possa situar e agir:

Coisa paradoxal, a desalienação não vai primeiro para frente, mas bem para trás por uma reflexão que me coloca em perspectiva: tanto em relação às possibilidades do meu presente (que podem ser poucas...) tanto ao 
possível que promete o futuro (que normalmente é muito amplo), tanto ao formidável processo de mudança que sofreu o passado (muito maior do que estamos pensando à primeira vista) (FURTER, 1968, p. 57).

O pensamento utópico, neste sentido, pressupõe não somente este ir para frente, mas está em estreita relação com um passado (pessoal e coletivo) já percorrido. A desalienação não implica necessariamente na afirmação de algo puramente novo, inédito, mas paradoxalmente na tomada de consciência de que o passado pode ser repetido, pois nada está fixado definitivamente na história. "O homem que tomou consciência do processo e da possibilidade da desalienação vai se empenhar numa tarefa em que o passado será a matéria do seu presente e o trampolim do seu futuro. O passado, de xadrez, transforma-se em mola, projetando o homem na ação" (Ibidem, p. 58).

A consciência utópica se apresenta como um telescópio potente aos indivíduos que estão presos à complexidade do emaranhado dos fatos que não os permite vislumbrar "além-de". A precisão da "lente" regulada neste telescópio é o que permite a clareza para apontar caminhos a serem percorridos, assim como a avaliação da velocidade do movimento a ser realizado. $\mathrm{O}$ pensamento utópico ilumina as circunstâncias obscuras da situação imediata com base naquilo que é vislumbrado à distância no futuro, mas que se espera alcançar e se aproximar por um instante (BLOCH, 2005, p. 23).

A visão daquele que sonha acordado amplia seu horizonte de abrangência e aumenta a clareza cognitiva da realidade, como se fosse um "telescópio potente", que auxilia o olhar histórico a se tornar sempre mais apurado diante das possibilidades que unem o "já" e o "ainda-não". Isso acontece num exercício de elasticidade do pensamento que aguça a intuição pela novidade e rechaça as vias que obstruem e dificultam o seu acesso. $\mathrm{O}$ ainda-não atualizado e mediado pela consciência é um movimento coerente entre o ser e o ser-mais, o "ser-em-possibilidade e conforme-a-possibilidade" (Ibidem, p. 203).

Daí que o conhecimento daquilo que se antecipa precisa se radicar numa ontologia paradoxal do "ainda-não", no "estar-sendo" da 
possibilidade e com base naquilo que "já-foi", pois a totalidade do real é incompleta, inacabada e inconclusa. Ela tende, quando mediada pela consciência humana - que também está-sendo, portanto é limitada historicamente -, para sua plenificação. O "Ser", neste sentido, compreende a totalidade da realidade em tendência para um "todo" latente ainda-não realizado, ao optimum, ou summum bonum que unifica e sintetiza toda expectativa dos sonhos despertos (Ibidem, p. 300).

Paradoxalmente, portanto, para o pensamento utópico "a gênese é o fim" (FURTER, 1968, p. 57). A "ontologia do aindanão" é a imanentização do Bem Supremo (Summum Bonum) que está transcendentalmente colocado, situado no futuro, mas não de maneira estática. Se em tudo há a abertura ao possível diferente, se deve considerar a contingência como fundamento para o "ser-em-manifestação", como se o bem absoluto pretendido e antecipado, cujo conteúdo está em "tendência-latência" no mundo, estivesse prestes a irromper na história. Este arquétipo que Bloch denomina de "puramente utópico" é evidente, e demonstra seus correlatos nos "ideais éticos como exemplos e estéticos como pré-aparências, indicando para algo que possivelmente pode se tornar real" (BLOCH, 2005, p. 172).

\section{O Pensamento Utópico e o paradoxo da formação humana - o problema de uma conclusão-inconclusa}

É preciso admitir que o pensamento utópico também exerce um papel pedagógico e formativo sobre o desenvolvimento da subjetividade/ intersubjetividade emancipatória dos indivíduos, estes que assumem o compromisso histórico de aprofundar as possibilidades do seu próprio “devir antropológico". É pedagógico, porque conduz os sujeitos dessa práxis na direção do exercício processual de sua liberdade criativa e criadora. É formativo, porque pretende forjar — intelectualmente e moralmente - consciências autônomas para que se orientem, estrategicamente, na 
opção de um "devir" sócio-histórico inédito, condição de possibilidade para a configuração desta liberdade a ser efetivada coletivamente.

Frente ao quadro da imutabilidade ou estagnação existencial, a "função" paradoxal do sonho acordado é estimular a reflexão crítica e ativa para "dar forma" ao "ainda-não-formado", continuar a construção do "ainda-não concluído" e realizar o "possível-não-realizado". Esta mútua relação entre utopia e formação, portanto, precisa ser discutida e compreendida conceitualmente, para que não desviemos o foco de nossa concepção dialética e antecipadora da educação. De acordo com Furter:

O formador adota diante do educando uma atitude análoga àquela do utópico que busca noutro lugar a realidade na qual ele acredita profundamente [...]. Do mesmo modo que a utopia pretende contribuir para a construção de um mundo melhor, também o formador está persuadido que é capaz de transformar o homem e os homens" (FURTER, 1977-1978, p. 2, Tradução nossa).

A analogia que Pierre Furter faz entre utopia e formação nos permite identificar o pressuposto de que os seres humanos, em sua sociabilidade, podem se aperfeiçoar pluridimensionalmente. Enquanto o pensamento utópico visa a antecipação da imagem do futuro almejado para a "trans-formação" do mundo, a ação formativa procura os meios de aperfeiçoar da melhor forma possível o educando, ou seja, "transformar" os seres humanos. A questão que se impõe à formação orientada pelo pensamento utópico, neste sentido, está em problematizar o "devirhumano", para que este dinamize o desenvolvimento de uma, dentre suas inúmeras possíveis "formas" sempre incompletas.

Isso implica em reconhecer o papel da consciência que se situa na história, rompe com as manipulações ideológicas e assume, ao se apropriar de ser devir potencial, a capacidade de ir "além" de qualquer condicionamento histórico. Assim, do mesmo modo que a utopia adquire uma dimensão formadora, a formação tem uma dimensão utópica. Sobre a cumplicidade desta relação, continua Furter: 
A convergência entre o pensamento utópico e a reflexão sobre a prática pedagógica não se situa somente no nível dos fundamentos. Se ambos parecem partir do mesmo princípio, o de que há mais possibilidades no real do que se supõe à primeira vista, eles convergem igualmente na certeza de que é possível dar uma forma concreta a estas possibilidades. Formar é intervir em função de um modelo que a formação valoriza mais do que os outros e que se apresenta como melhor em relação àquele em que se está. Desta forma, a utopia propõe os modelos em função dos quais é possível tomar distância da realidade omnipresente. Ela tem sempre raízes contingentes e está historicamente situada, pois não existe e não se afirma a não ser na medida em que nega e se opõe e, em todo o caso onde ela se inscreve como contraponto de uma dada situação. Assim, não há formação possível a não ser na negação praticada de uma "natureza" recebida e adquirida. É por que a formação remete tanto a um homem novo quanto a um homem velho que se trata de remodelar, de eliminar, ou de superar. O adulto é tanto a realização da criança quanto a sua perpétua negação (FURTER, 1977/1978, p. 3-4, Tradução nossa).

Eis aqui um dos paradoxos desta relação entre o pensamento utópico e a formação humana. Na mesma medida em que a utopia fornece o "modelo", cujos valores são preferíveis aos existentes, este se afirma na medida em que os nega. Mas esta negação também pressupõe uma afirmação, ou seja, o adulto é tanto a realização da criança quanto sua perpétua negação, o que nos permite compreender o devir como uma condição da constituição antropológica. O devir é tanto a afirmação de uma possibilidade do ser, quanto a negação de inúmeras outras possibilidades.

Pierre Furter chama a atenção para o fato de que a atividade formadora, assim como a utopia, sempre pressupõe a negação de uma realidade dada, de uma "natureza" recebida, contrapondo-se à esclerose do envelhecido em nome da memória vivaz da jovialidade, sem negá-lo completamente, pois este é condição para sua existência.

A "forma” pela qual se engaja aquele que está imbuído do pensamento utópico é a insubordinação às estruturas totalizantes da realidade que engessam a história e pretendem perenizar sua contingência futuro adentro. Portanto, orientar a formação humana no sentido de um 
modelo, cujo valor é superior, significa tomá-lo como referência para a realização das potencialidades humanas que são obstruídas diante de uma dada circunstância num determinado tempo.

Para assumir que a formação humana seja uma sucessiva sequência de afirmação de possibilidades, não significa que todas elas se consumam em seu máximo potencial, pois o fracasso, enquanto interrupção de uma possibilidade assumida, também é inerente ao processo histórico de efetivação da subjetividade/intersubjetividade. A condição chave para o pensamento utópico está em desenvolver a perspicácia intuitiva de sempre continuar captando as possibilidades e tendências humanas para além da aparente "dureza incontornável" dos fatos, a fim de que a consciência não se adapte à ilusão da aparente intransponibilidade dos obstáculos encontrados.

A noção de formação, nesta perspectiva, precisa ser compreendida dialeticamente para não ser reduzida ao idealismo, ou essencialismo, de um lado, nem ao objetivismo ou mecanicismo, de outro. O idealista pretende dar forma à ideia que tem, pois quer realizar um modelo universal independente das circunstâncias históricas em que se encontra. O mecanicista, por outro lado, age como se a "forma" já estivesse afixada no futuro, cabendo-lhe a tarefa de explicitá-la em seus próprios termos na realidade imediata.

Contudo, a perspectiva dialética da reflexão sobre a realidade do ser humano e do mundo permite que a formação orientada pelo pensamento utópico compreenda a "forma" contingencialmente projetada como um momento da superação a ser realizada que, no entanto, ainda não atingiu e, jamais atingirá plenamente sua completude. Isso porque tem como fim o homo absconditus (BLOCH, 2005/2006, p. 369), o ser humano além-presente, ainda-não-acabado, porque encerra a potência da sua identidade no futuro, da qual é possível se aproximar somente com a "prática da liberdade". Esta consiste num exercício do desenvolvimento da vocação humana para "ser mais" (FREIRE, 2003, p. 207). Adriano Nogueira exprime o sentido de sua intencionalidade no prefácio que faz ao livro de Paulo Freire, Cartas à Cristina (2003): 
O Ser Humano extrai de si e de suas interações uma sobre-humanidade (a que ele denomina de vocação para ser mais). E educar (exducere) é extrair ou, usando termos "freirinanos", é partejar. O Ser Humano parteja sua sobre-humanidade educando-se para ela. Na concepção de Paulo, a educação é uma certa antecipação: a prática educativa antecipa o "ser mais" do Ser Humano (os termos dele são: o gosto pela liberdade) (NOGUEIRA, 2003, p. 15).

Neste sentido, emergem algumas questões: existiria uma "forma" específica deste "ser mais"? Ou, teríamos que admitir, como afirmou Nogueira, que há um partejamento de uma "sobre-humanidade"? Haveria um partejamento definitivo ou deveríamos estar sempre partejando (antecipando?), por meio da formação, o "ser mais" que desconhecemos em nós mesmos? Acreditamos que a reflexão sobre essas questões antropológicas deve considerar a justa medida (jamais exata) entre as "equivalências potenciais" e as "factibilidades possíveis".

As potencialidades humanas, ignoradas ou desconhecidas, e as possibilidades históricas ainda não experimentadas, envolvem o nó da questão para concretização da utopia compreendida como antecipação no processo formativo.

Um processo pedagógico que conjugue o desenvolvimento do "ser mais-potencial" humano, em conformidade com o "ser mais-possível" na realidade, implica que o ser humano tome consciência dos limites de sua ação situada em seu contexto particular. Desse contexto, este referencia sua universalidade e rompe com a sobreposição das forças condicionantes - jamais determinantes. O pensamento pedagógico utópico, nesses termos, procura problematizar continuamente a compreensão do "ser conforme-a-possibilidade", cuja tendência é a conformação aos fatos para "ser-em-possibilidade" sempre com o olhar visionário no horizonte do "além-possível". Desvenda, assim, e combate continuamente as forças manipuladoras da história e busca a antecipação do possível ainda inédito.

O critério das potencialidades ou impotencialidades humanas, frente às possibilidades ou impossibilidades históricas, mais uma vez remete à medida paradoxal da práxis e da esperança/utopia. O pensamento 
utópico é como um farol que ilumina as "sombras" da dominação ideológica que impedem os indivíduos dominados de vislumbrar os horizontes das possibilidades históricas para a efetivação do seu devir. Por isso, estimula a reflexão crítica para aguçar a sensibilidade criativa e criadora sobre as potencialidades viáveis inscritas nesta mesma realidade.

A itinerância da consciência que conjuga a contextualização do potencial humano diante das suas possibilidades históricas, tendo o futuro como locus do anúncio, o presente como um problema, e o passado como mola propulsora, é a "forma" contingente a ser sempre buscada, superada permanentemente, a tensão entre a vivência conflitiva da vocação que desafia a humanidade para se ultrapassar, bem como o risco de sua própria negação.

Portanto, à guisa de conclusão, é necessário deixar claro que a atividade formadora utópica não pressupõe que alguém modele a outrem, a fim de imprimir as marcas de sua ação, como um artista faz ao lapidar uma estátua. Refere-se, sim, ao despertar este outrem (ou os outros), para que seja (sejam) objeto de sua própria formação. E, assim, que assuma a tarefa contínua de ser artífice de si mesmo em sua sociabilidade, cuja busca pelo "ser mais" se faça a condição para a busca contínua de sua própria conclusão (que se reconhece, conscientemente, inconclusa, justamente porque histórica).

\section{Referências}

AINSA, F. Les Utopies sont mortes, vive l'utopie! In: LE COURRIEUR DE L'UNESCO. Les Utopies, ou la quête de l'impossible. n. 2, février. Paris: UNESCO, 1991.

Agostinho. A Cidade de Deus (Contra os Pagãos), Parte I: Livros I a X; Parte II: Livros XI a XXII. Trad. Oscar Paes Leme. Petrópolis, RJ: Vozes; São Paulo: Federação Agostiniana Brasileira; Bragança Paulista, SP: Editora Universitária São Francisco, 2012. (Vozes de Bolso). 
BLOCH, E. O Princípio Esperança. v. 1. Trad. Nélio Shneider - Rio de Janeiro: EdUERJ: Contraponto, 2005.

BLOCH, E. O Princípio Esperança. v. 2. Trad. Werner Fuchs - Rio de Janeiro: EdUERJ: Contraponto, 2006.

BLOCH, E. O Princípio Esperança. v. 3. Trad. Nélio Shneider - Rio de Janeiro: EdUERJ: Contraponto, 2005/2006.

BIBLIA SAGRADA. A Bíblia de Jerusalém. Editora Paulus: São Paulo, 2001.

CAMBI, F. História da pedagogia. Trad. Álvaro Lorencini. São Paulo: UNESP (FEU), 1999.

FREIRE, P. Cartas à Cristina: Reflexões sobre minha vida e minha práxis. (Org.) Ana M. Freire. 2. ed. rev. São Paulo: UNESP, 2003.

FURTER, P. A dialética da esperança: interpretação do pensamento de Ernst Bloch. São Paulo: Paz e Terra, 1968.

FURTER, P. L’Amérique Utopique: Essai sur la contribution de la pensée utopique au developpement de la formation des latino-americains. 1977 - 1978. (Apostila mimeografada para uso nas aulas no curso da FAPSE - UNIGENEVE).

JAEGER, W. Paideia: a formação do homem grego. Trad. Artur M. Parreira; 5. ed. São Paulo: WMF Martins Fontes, 2010.

KEMPIS, T. de. Imitação de Cristo: textos escolhidos. Trad. Emérico da Gama. São Paulo: Quadrante, 1987

MORE, T. A utopia. São Paulo: Nova Cultural, 1997.

MORA, J. F. Dicionário de Filosofia. Tomo III (K-P). São Paulo: Edições Loyola, 2004. NOGUEIRA, A. Prefácio. In: FREIRE, P.; FREIRE, A. M. Cartas à Cristina: Reflexões sobre minha vida e minha práxis (org.). 2. ed. rev. São Paulo: UNESP, 2003.

PLATÃO. A República. Trad. Anna Lia Amaral de Almeida Prado, rev. técnica e introd. Roberto Bolzani Filho. São Paulo: Martins Fontes, 2006. 
QUARTA, C. Utopia: gênese de uma palavra-chave. Morus, utopia e renascimento. n. 3, FAEPEX/UNICAMP, 2006.

SEVERINO, A. J. A busca de sentido da formação humana: tarefa da filosofia da educação. Educação e Pesquisa, São Paulo, v. 32, n. 3, p. 619-634, set./dez. 2006.

Recebido: 27/08/2018

Recibido: 27/08/2018

Received: 08/27/2018

Aprovado: 28/10/2018

Aprobado: 28/10/2018

Approved: 10/28/2018 